\title{
THE RELATIONSHIP OF SERUM HEXOSAMINE, GLOBULINS, AND ANTIBODIES TO EXPERIMENTAL AMYLOIDOSIS ${ }^{1}$
}

\author{
By ROBERT B. GILES, JR., 2, 8 AND EVAN CALKINS \\ (From the Department of Medicine, Harvard Medical School, and the Medical Service of the \\ Massachusetts General Hospital, Boston, Mass.)
}

(Submitted for publication January 2, 1958; accepted February 20, 1958)

Amyloid as a disease in human beings occurs not only de novo, but also secondary to a variety of chronic infectious diseases, to rheumatoid arthritis, and to multiple myeloma. These apparently unrelated diseases may, therefore, have some characteristics in common, as evidenced by their ability to produce amyloid. Knowledge of the specific biological alterations that are responsible for secondary amyloidosis may highlight certain factors common to these diverse primary diseases as well as aid in elucidating the basic physiological alterations responsible for the disease process of rheumatoid arthritis, which is complicated by a high incidence of amyloidosis.

Secondary amyloidosis has been produced in experimental animals by numerous workers (111). Whether the amyloid produced in experimental animals is identical in chemical structure and pathogenesis to the primary and secondary amyloid found in human beings has not been established. Though several workers have pointed out the frequency with which hyperglobulinemia occurs $(2,3,7,12,13)$, others have demonstrated that alterations in blood lipoproteins ( 7 ) and elevation of the serum hexosamine (14) occur. On the basis of these observations it has been suggested that amyloid may be the product of an antigen-antibody precipitate $(13,15,16)$ or the indirect result of other immunological reactions.

1 This is publication No. 225 of the Robert W. Lovett Memorial for the Study of Crippling Diseases, Harvard Medical School, Boston, Mass. Grants in support of these investigations have been received from the Commonwealth Fund, New York, N. Y., and from the Milton Fund of Harvard University.

2 This work performed while a Public Health Service Postdoctoral Research Fellow of the National Institute of Arthritis and Metabolic Diseases, National Institutes of Health.

3 Present address: Department of Internal Medicine, The University of Texas Southwestern Medical School, Dallas, Texas.
The purpose of this study was to produce secondary amyloidosis in a series of rabbits in order to 1) examine and relate the biochemical and in!munological derangements that occurred during the development of amyloidosis, and 2) compare the chemical composition of amyloid with that found in human beings. Results of the studies of the chemical identity of these types of amyloid will appear in a separate report. The observations reported here demonstrate that elevation of serum globulins and, particularly, of the serum protein bound hexosamine occurs in all animals developing amyloidosis, whereas there was no correlation between the precipitable antibody titer and the degree of amyloidosis.

\section{MATERIAL AND METHODS}

Plan of study. The study was divided into two parts, performed during successive years. In the initial study (A), a group of 12 rabbits, of the same strain of New Zealand whites, and weighing approximately $3 \mathrm{Kg}$. each, was subjected to biweekly subcutaneous injections of 5 $\mathrm{ml}$. of 10 per cent casein suspended in water, to which penicillin was added in a dose of 1,000 units per ml. The suspension was injected subcutaneously into the back of the rabbit, a different site being selected for each injection. Three additional rabbits of the same strain, age and weight were kept as uninjected controls. The rabbits were bled periodically by intracardiac puncture, about $20 \mathrm{ml}$. being withdrawn each time. The blood was allowed to clot, and the serum was stored at $-20^{\circ} \mathrm{C}$. until time of analysis.

Of the original group of 12 injected rabbits, four died at three months or less-one of infection, one with convulsions immediately following casein injection, one of nephritis, and one following intracardiac puncture. These rabbits were eliminated from the study; none displayed histologic evidence of amyloidosis at autopsy. The eight remaining rabbits received biweekly injections and were bled at two month intervals for 6 to 15 months. Five were sacrificed; three died-one (No. 18) with a severe groin abscess, and two (Nos. 12 and 13) shortly after casein injections. The clinical and histological data and the result of analyses of the serum obtained at the serial bleedings are recorded in Tables I and II, under Group A. 
TABLE I

Clinical and pathological observations of all rabbits in study

\begin{tabular}{|c|c|c|c|c|c|c|c|}
\hline $\begin{array}{c}\text { Rabbit } \\
\text { no. }\end{array}$ & Sex & $\begin{array}{l}\text { No. of } \\
\text { injec- } \\
\text { tions }\end{array}$ & $\begin{array}{l}\text { Months } \\
\text { until } \\
\text { death }\end{array}$ & $\begin{array}{l}\text { Mode of } \\
\text { death }\end{array}$ & $\begin{array}{l}\text { Amyloid } \\
\text { in spleen }\end{array}$ & $\begin{array}{l}\text { Amyloid } \\
\text { in kidney }\end{array}$ & Comments \\
\hline
\end{tabular}

Controls

$\begin{array}{lllll}23 & + & 0 & 15.5 & \text { Sacrificed } \\ 24 & q & 0 & 15 & \text { Sacrificed }\end{array}$

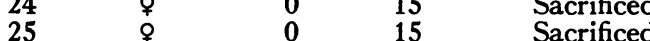

Group A

$10 \%$ casein twice weekly

\begin{tabular}{|c|c|c|c|c|c|c|}
\hline $\begin{array}{r}18 \\
8 \\
14\end{array}$ & $\begin{array}{l}q \\
q \\
q\end{array}$ & $\begin{array}{l}42 \\
82 \\
71\end{array}$ & $\begin{array}{l}6 \\
11.5 \\
10.5\end{array}$ & $\begin{array}{c}\text { Died } \\
\text { Sacrificed } \\
\text { Sacrificed }\end{array}$ & $\begin{array}{l}++ \\
++ \\
++\end{array}$ & $\begin{array}{c}\stackrel{ \pm}{ \pm} \\
+++\end{array}$ \\
\hline $\begin{array}{r}9 \\
17\end{array}$ & $\begin{array}{l}q \\
q\end{array}$ & $\begin{array}{r}100 \\
87\end{array}$ & $\begin{array}{l}15 \\
13\end{array}$ & $\begin{array}{l}\text { Sacrificed } \\
\text { Sacrificed }\end{array}$ & $\begin{array}{c}++ \\
+\end{array}$ & + \\
\hline $\begin{array}{l}13 \\
11 \\
12\end{array}$ & $\begin{array}{l}9 \\
9 \\
9 \\
q\end{array}$ & $\begin{array}{r}64 \\
100 \\
92\end{array}$ & $\begin{array}{l}8.5 \\
15 \\
13.5\end{array}$ & $\begin{array}{c}\text { Died } \\
\text { Sacrificed } \\
\text { Died }\end{array}$ & $\begin{array}{l}+ \\
+ \\
\pm\end{array}$ & $\begin{array}{l}0 \\
0 \\
+\end{array}$ \\
\hline
\end{tabular}

$\begin{array}{ll}0 & 0 \\ 0 & 0 \\ 0 & 0\end{array}$

$\begin{gathered}\text { Severe nephritis; pulmonary } \\ \text { intra-arterial hyaline de- } \\ \text { posits }\end{gathered}$
positis

\begin{tabular}{|c|c|c|c|c|c|c|c|c|c|c|}
\hline \multirow[b]{2}{*}{$\begin{array}{c}\text { Rabbit } \\
\text { no. }\end{array}$} & \multirow[b]{2}{*}{ Sex } & \multirow{2}{*}{$\begin{array}{l}\text { No. of } \\
\text { injec- } \\
\text { tions }\end{array}$} & \multirow{2}{*}{$\begin{array}{l}\text { Months } \\
\text { until } \\
\text { death }\end{array}$} & \multirow[b]{2}{*}{$\begin{array}{l}\text { Mode of } \\
\text { death }\end{array}$} & \multirow{2}{*}{$\begin{array}{c}\text { Time of } \\
\text { biopsy } \\
\text { (months) }\end{array}$} & \multirow{2}{*}{$\begin{array}{l}\text { Amyloid } \\
\text { in spleen } \\
\text { at biopsy }\end{array}$} & \multicolumn{2}{|c|}{ Amyloid at death } & \multirow[b]{2}{*}{$\begin{array}{c}\text { Degree of } \\
\text { emaciation }\end{array}$} & \multirow{2}{*}{$\begin{array}{c}\text { Sub- } \\
\text { cutaneous } \\
\text { nodules }\end{array}$} \\
\hline & & & & & & & In spleen & In kidney & & \\
\hline
\end{tabular}

$10 \%$ casein twice weekly

\begin{tabular}{|c|c|c|c|c|c|c|c|c|c|c|}
\hline $\begin{array}{l}67 \\
69\end{array}$ & $\begin{array}{l}9 \\
9 \\
9\end{array}$ & $\begin{array}{l}46 \\
57\end{array}$ & $\begin{array}{l}4 \\
7\end{array}$ & $\begin{array}{l}\text { Spontaneous } \\
\text { Sacrificed }\end{array}$ & & & $\begin{array}{c}++t \\
+++t\end{array}$ & $\underset{\text { Minimal }}{0}$ & $\begin{array}{c}+t \\
+++\end{array}$ & \\
\hline 58 & 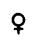 & 53 & $6 \frac{1}{3}$ & Sacrificed & 3.5 & + & +++ & +++ & +++ & Yes \\
\hline $\begin{array}{l}56 \\
55\end{array}$ & $\begin{array}{l}\stackrel{9}{9} \\
9\end{array}$ & $\begin{array}{l}37 \\
59\end{array}$ & $7^{6 \frac{2}{3}}$ & $\begin{array}{l}\text { Found dead } \\
\text { Found dead }\end{array}$ & $\begin{array}{l}3.5 \\
3.5\end{array}$ & ++ & $\begin{array}{l}++++ \\
+++\end{array}$ & $\frac{++}{+++}$ & $\begin{array}{c}0 \\
++\end{array}$ & $\begin{array}{l}\text { Yes } \\
\text { No }\end{array}$ \\
\hline $\begin{array}{l}59 \\
47\end{array}$ & $\begin{array}{l}\circ \\
\sigma^{7}\end{array}$ & $\begin{array}{l}74 \\
60\end{array}$ & $\begin{array}{l}9 \\
6\end{array}$ & $\begin{array}{l}\text { Sacrificed } \\
\text { Found dead }\end{array}$ & 3.5 & $\mathbf{0}$ & $\begin{array}{c}+++ \\
++\end{array}$ & $\begin{array}{c}\text { (Pyelonephritis) } \\
+++ \\
++\end{array}$ & ++ & No \\
\hline 60 & \% & 68 & $8 \frac{1}{4}$ & Sacrificed & & & ++ & +++ & 0 & Yes \\
\hline \multicolumn{11}{|c|}{ ingle injection $10 \%$ casein } \\
\hline 61 & 우 & 1 & 8 & Sacrificed & 3.5 & 0 & +++ & \multicolumn{3}{|c|}{0 (Severe renal tubular damage) } \\
\hline
\end{tabular}

Following completion of this study, a second study (B) was commenced. One group of six rabbits was studied in an identical manner to those described above, except that prior to the first injection the animals were anesthetized with Nembutalis and their spleens were eased through a muscular incision and fixed subcutaneously at the lower rib margin.4 An initial biopsy was obtained at this time. Repeat biopsy was obtained after three and one-half months by way of a cutaneous incision. Unfortunately, the adhesions were often so dense that it was felt that it would have been easier to re-biopsy the spleen in its natural location. These six rabbits, together with two additional rabbits whose spleens had not been trans-

* This procedure was performed by Messrs. Bob Bulwinkel and Donovan A. Baumgartner of the Harvard Medical School. planted, received serial injections of 10 per cent casein twice weekly. All of these animals developed amyloidosis and are included in Table I (Group B). In addition, three animals with spleen transplants received only one injection of casein. One (No. 61) developed massive amyloidosis and is included in Group B, Table I. The other two did not show signs of amyloidosis when sacrificed after 8 and 12 months, respectively, nor did they exhibit any of the chemical or immunological alterations noted in the animals with amyloidosis and so were not included in the series.

The animals were bled by intracardiac puncture before beginning the casein injections and at one to two month intervals until death. The serum was stored in the deep freeze. Sacrifice was performed by exsanguination. As soon as possible after death, each animal was examined 
TABLE II

Chemical and immunologic observations of all rabbits in study

\begin{tabular}{|c|c|c|c|c|c|c|c|c|}
\hline \multirow{3}{*}{$\begin{array}{c}\text { Rabbit } \\
\text { no. }\end{array}$} & \multirow{3}{*}{$\begin{array}{l}\text { Time in } \\
\text { months }\end{array}$} & \multicolumn{7}{|c|}{ Serum concentration } \\
\hline & & \multirow[b]{2}{*}{ Alb. } & \multicolumn{3}{|c|}{ Globulins } & \multirow{2}{*}{$\begin{array}{c}\text { Casein } \\
\text { antibody }\end{array}$} & \multirow[b]{2}{*}{ Hexosamine } & \multirow[b]{2}{*}{ NPN } \\
\hline & & & Alpha & Beta & Gamma & & & \\
\hline \multicolumn{9}{|c|}{ Group A } \\
\hline Controls & & Gm. \% & $\mathrm{Gm} . \%$ & Gm.\% & $G m . \%$ & $\mu g . N / m l$. & mg. $\%$ & mg. \% \\
\hline 23 & $\begin{array}{r}0 \\
8 \\
12 \\
13 \\
15\end{array}$ & $\begin{array}{l}3.9 \\
4.5 \\
4.0 \\
4.3 \\
4.5\end{array}$ & $\begin{array}{l}0.6 \\
0.6 \\
0.5 \\
0.6 \\
0.6\end{array}$ & $\begin{array}{l}0.4 \\
0.5 \\
0.5 \\
0.5 \\
0.7\end{array}$ & $\begin{array}{l}0.6 \\
0.6 \\
0.5 \\
0.4 \\
0.7\end{array}$ & $\begin{array}{l}\mathbf{0} \\
\mathbf{0} \\
\mathbf{0} \\
\mathbf{0} \\
\mathbf{0}\end{array}$ & $\begin{array}{l}83 \\
66 \\
66 \\
79 \\
91\end{array}$ & $*$ \\
\hline 24 & $\begin{array}{r}0 \\
12 \\
13 \\
15\end{array}$ & $\begin{array}{l}5.2 \\
4.5 \\
4.6 \\
4.9\end{array}$ & $\begin{array}{l}0.9 \\
0.8 \\
1.0 \\
0.5\end{array}$ & $\begin{array}{l}0.7 \\
0.6 \\
0.7 \\
0.4\end{array}$ & $\begin{array}{l}0.7 \\
0.6 \\
0.5 \\
0.7\end{array}$ & $\begin{array}{l}0 \\
0 \\
0 \\
0\end{array}$ & $\begin{array}{r}85 \\
87 \\
101 \\
79\end{array}$ & 46 \\
\hline 25 & $\begin{array}{r}0 \\
12 \\
13 \\
15\end{array}$ & $\begin{array}{l}4.1 \\
3.9 \\
4.1 \\
4.0\end{array}$ & $\begin{array}{l}0.6 \\
0.5 \\
0.6 \\
0.5\end{array}$ & $\begin{array}{l}0.5 \\
0.5 \\
0.4 \\
0.7\end{array}$ & $\begin{array}{l}0.6 \\
0.6 \\
0.7 \\
0.6\end{array}$ & $\mathbf{0}$ & $\begin{array}{l}70 \\
62 \\
70 \\
88\end{array}$ & 35 \\
\hline $\begin{array}{l}\text { Mean of } \\
\text { controls }\end{array}$ & . & $\begin{array}{l}4.3 \pm 0.5 \\
(\mathrm{~N}=37) \dagger\end{array}$ & $\begin{array}{c}0.64 \pm 0.15 \\
(\mathrm{~N}=37)\end{array}$ & $\begin{array}{c}0.58 \pm 0.13 \\
(\mathrm{~N}=37)\end{array}$ & $\begin{array}{c}0.81 \pm 0.3 \\
(\mathrm{~N}=37)\end{array}$ & & $\begin{array}{l}77.3 \pm 8 \\
(\mathrm{~N}=19)\end{array}$ & \\
\hline \multicolumn{9}{|c|}{$10 \%$ casein S.C. twice weekly } \\
\hline 18 & $\begin{array}{l}\mathbf{0} \\
2 \\
3 \\
5\end{array}$ & $\begin{array}{l}4.6 \\
3.2 \\
3.0 \\
3.8\end{array}$ & $\begin{array}{l}0.7 \\
0.8 \\
0.8 \\
1.0\end{array}$ & $\begin{array}{l}0.5 \\
0.7 \\
0.8 \\
0.9\end{array}$ & $\begin{array}{l}0.7 \\
2.1 \\
2.2 \\
3.2\end{array}$ & $\begin{array}{c}0 \\
710 \\
280 \\
435\end{array}$ & $\begin{array}{r}82 \\
129 \\
116 \\
137\end{array}$ & $\begin{array}{l}39 \\
85\end{array}$ \\
\hline 8 & $\begin{array}{c}0 \\
2 \\
3 \\
5 \\
8 \\
10 \\
11 \\
2 \text { days } ¥ \\
5 \text { days } \\
7 \text { days } \\
10 \text { days }\end{array}$ & $\begin{array}{l}4.4 \\
3.1 \\
4.3 \\
4.0 \\
3.8 \\
3.6 \\
3.0 \\
3.4 \\
3.0 \\
3.0 \\
3.1\end{array}$ & $\begin{array}{l}0.5 \\
0.7 \\
0.8 \\
0.5 \\
0.6 \\
0.7 \\
1.0 \\
1.0 \\
0.9 \\
0.9 \\
0.6\end{array}$ & $\begin{array}{l}0.5 \\
1.0 \\
0.9 \\
0.4 \\
0.7 \\
0.7 \\
0.9 \\
1.0 \\
0.9 \\
0.8 \\
0.7\end{array}$ & $\begin{array}{l}0.7 \\
2.4 \\
1.9 \\
1.3 \\
1.4 \\
1.5 \\
1.7 \\
1.4 \\
1.0 \\
0.8 \\
0.7\end{array}$ & $\begin{array}{c}0 \\
0 \\
175 \\
0 \\
175 \\
0 \\
85 \\
0 \\
0 \\
0 \\
0\end{array}$ & $\begin{array}{r}83 \\
110 \\
124 \\
83 \\
112 \\
104 \\
124 \\
139 \\
108 \\
108 \\
120\end{array}$ & 42 \\
\hline 14 & $\begin{array}{r}0 \\
2 \\
3 \\
5 \\
8 \\
10 \\
11\end{array}$ & $\begin{array}{l}4.1 \\
4.0 \\
3.4 \\
4.1 \\
2.8 \\
1.0 \\
1.7\end{array}$ & $\begin{array}{l}0.9 \\
1.0 \\
1.1 \\
0.7 \\
1.1 \\
1.3 \\
1.5\end{array}$ & $\begin{array}{l}0.7 \\
0.9 \\
0.9 \\
0.5 \\
0.7 \\
0.5 \\
0.7\end{array}$ & $\begin{array}{l}1.1 \\
2.0 \\
1.8 \\
1.2 \\
1.9 \\
1.5 \\
2.3\end{array}$ & $\begin{array}{r}0 \\
40 \\
35 \\
145 \\
50 \\
185 \\
0\end{array}$ & $\begin{array}{r}81 \\
118 \\
112 \\
77 \\
122 \\
110 \\
124\end{array}$ & $\begin{array}{l}40 \\
96\end{array}$ \\
\hline 9 & $\begin{array}{r}0 \\
2 \\
3 \\
5 \\
8 \\
10\end{array}$ & $\begin{array}{l}4.3 \\
3.1 \\
3.0 \\
3.7 \\
3.5 \\
3.8\end{array}$ & $\begin{array}{l}0.6 \\
0.7 \\
0.8 \\
0.7 \\
0.8 \\
0.6\end{array}$ & $\begin{array}{l}0.6 \\
0.8 \\
0.6 \\
0.6 \\
0.6 \\
0.5\end{array}$ & $\begin{array}{l}1.0 \\
1.9 \\
1.4 \\
1.5 \\
1.9 \\
2.6\end{array}$ & $\begin{array}{c}0 \\
0 \\
285 \\
0 \\
0 \\
0\end{array}$ & $\begin{array}{r}73 \\
91 \\
112 \\
79 \\
91 \\
96\end{array}$ & 35 \\
\hline 17 & $\begin{array}{r}0 \\
2 \\
3 \\
5 \\
8 \\
10 \\
12 \\
13\end{array}$ & $\begin{array}{l}4.2 \\
4.0 \\
3.0 \\
3.4 \\
3.6 \\
3.2 \\
1.2 \\
1.9\end{array}$ & $\begin{array}{l}0.5 \\
0.7 \\
0.9 \\
0.6 \\
0.7 \\
1.0 \\
1.1 \\
1.3\end{array}$ & $\begin{array}{l}0.6 \\
0.6 \\
0.9 \\
0.8 \\
0.8 \\
1.0 \\
0.9 \\
0.8\end{array}$ & $\begin{array}{l}0.5 \\
1.2 \\
1.0 \\
1.0 \\
1.1 \\
1.0 \\
0.9 \\
0.8\end{array}$ & $\begin{array}{l}0 \\
0 \text {-trace } \\
0 \\
0 \text {-trace } \\
0 \\
0 \text {-trace } \\
0 \\
0 \text {-trace }\end{array}$ & $\begin{array}{r}62 \\
83 \\
104 \\
79 \\
91 \\
104 \\
100 \\
112\end{array}$ & $\begin{array}{l}66 \\
86\end{array}$ \\
\hline
\end{tabular}

* Blank indicates not measured.

$\dagger \mathrm{N}$ includes the control or pre-injection values taken on many treated animals.

$\ddagger$ Days of cortisone injection. 
TABLE II-Continued

\begin{tabular}{|c|c|c|c|c|c|c|c|c|}
\hline \multirow{3}{*}{$\begin{array}{c}\text { Rabbit } \\
\text { no. }\end{array}$} & \multirow{3}{*}{$\begin{array}{l}\text { Time in } \\
\text { months }\end{array}$} & \multicolumn{7}{|c|}{ Serum concentration } \\
\hline & & \multirow[b]{2}{*}{ Alb. } & \multicolumn{3}{|c|}{ Globulins } & \multirow{2}{*}{$\begin{array}{c}\text { Casein } \\
\text { antibody }\end{array}$} & \multirow[b]{2}{*}{ Hexosamine } & \multirow[b]{2}{*}{ NPN } \\
\hline & & & Alpha & Beta & Gamma & & & \\
\hline \multicolumn{9}{|c|}{ Group A-Continued } \\
\hline 13 & $\begin{array}{l}0 \\
2 \\
3 \\
5 \\
8 \\
9\end{array}$ & $\begin{array}{c}G m . \% \\
4.1 \\
3.6 \\
3.4 \\
4.7 \\
3.6 \\
4.1\end{array}$ & $\begin{array}{c}G m . \% \\
0.8 \\
0.8 \\
1.0 \\
1.0 \\
0.9 \\
0.6\end{array}$ & $\begin{array}{c}\text { Gm. \% } \\
0.6 \\
0.8 \\
0.8 \\
0.9 \\
0.6 \\
0.5\end{array}$ & $\begin{array}{c}G m . \% \\
1.7 \\
1.6 \\
1.3 \\
2.0 \\
1.7 \\
1.3\end{array}$ & $\begin{array}{c}\mu g . N / m l . \\
0 \\
0 \\
0 \\
\text { trace } \\
0 \\
0\end{array}$ & $\begin{array}{c}\text { mg. } \% \\
89 \\
97 \\
89 \\
104 \\
97 \\
89\end{array}$ & $\begin{array}{l}59 \\
45\end{array}$ \\
\hline 11 & $\begin{array}{r}0 \\
2 \\
3 \\
5 \\
8 \\
10 \\
12 \\
13 \\
14 \\
15\end{array}$ & $\begin{array}{l}5.4 \\
3.7 \\
3.2 \\
4.5 \\
4.1 \\
4.4 \\
4.0 \\
4.1 \\
4.3 \\
4.9\end{array}$ & $\begin{array}{l}0.4 \\
0.6 \\
0.5 \\
0.7 \\
0.7 \\
0.7 \\
0.7 \\
0.8 \\
0.8 \\
0.4\end{array}$ & $\begin{array}{l}0.4 \\
0.7 \\
0.5 \\
0.6 \\
0.8 \\
0.7 \\
0.8 \\
0.9 \\
0.7 \\
0.5\end{array}$ & $\begin{array}{l}0.6 \\
1.8 \\
1.3 \\
1.4 \\
1.6 \\
1.4 \\
1.3 \\
1.4 \\
1.4 \\
1.0\end{array}$ & $\begin{array}{l}0 \\
0 \\
0 \text {-trace } \\
0 \\
55 \\
0 \\
10 \\
0 \\
0 \\
0\end{array}$ & $\begin{array}{r}66 \\
99 \\
108 \\
83 \\
83 \\
91 \\
108 \\
99 \\
\\
91\end{array}$ & 37 \\
\hline 12 & $\begin{array}{r}0 \\
2 \\
3 \\
5 \\
8 \\
10 \\
12 \\
13\end{array}$ & $\begin{array}{l}3.6 \\
3.8 \\
3.4 \\
4.0 \\
4.0 \\
3.8 \\
2.8 \\
1.8\end{array}$ & $\begin{array}{l}0.5 \\
0.8 \\
0.5 \\
0.6 \\
0.6 \\
0.6 \\
0.6 \\
0.9\end{array}$ & $\begin{array}{l}0.5 \\
0.7 \\
0.5 \\
0.5 \\
0.7 \\
0.7 \\
0.7 \\
0.9\end{array}$ & $\begin{array}{l}1.2 \\
1.9 \\
1.4 \\
1.4 \\
2.2 \\
1.4 \\
1.4 \\
1.2\end{array}$ & $\begin{array}{l}\mathbf{0} \\
\mathbf{0} \\
\text { trace } \\
0 \\
0 \\
\text { trace } \\
0 \\
\text { trace }\end{array}$ & $\begin{array}{r}79 \\
104 \\
89 \\
83 \\
75 \\
87 \\
99 \\
99\end{array}$ & $\begin{array}{l}51 \\
43\end{array}$ \\
\hline $10 \%$ са & \multicolumn{8}{|c|}{ Group B } \\
\hline 67 & $\begin{array}{l}0 \\
2 \\
4\end{array}$ & $\begin{array}{l}2.5 \\
2.4 \\
2.4\end{array}$ & $\begin{array}{l}0.8 \\
0.7 \\
0.4\end{array}$ & $\begin{array}{l}1.1 \\
0.6 \\
1.0\end{array}$ & $\begin{array}{l}1.1 \\
1.1 \\
1.2\end{array}$ & $\begin{array}{l}0 \\
1\end{array}$ & $\begin{array}{r}102 \\
92 \\
164\end{array}$ & $\begin{array}{l}31 \\
33\end{array}$ \\
\hline 69 & $\begin{array}{l}0 \\
2 \\
4 \\
6\end{array}$ & $\begin{array}{l}4.1 \\
2.6 \\
2.1 \\
2.4\end{array}$ & $\begin{array}{l}0.5 \\
0.6 \\
1.0 \\
0.8\end{array}$ & $\begin{array}{l}0.5 \\
0.7 \\
0.8 \\
0.9\end{array}$ & $\begin{array}{l}0.7 \\
1.9 \\
2.3 \\
2.1\end{array}$ & $\begin{array}{l}0 \\
6 \\
9\end{array}$ & $\begin{array}{r}77 \\
130 \\
118 \\
145\end{array}$ & \\
\hline 58 & $\begin{array}{l}0 \\
2 \\
3 \\
5 \\
6\end{array}$ & $\begin{array}{l}3.1 \\
4.4 \\
2.6 \\
2.0 \\
1.5\end{array}$ & $\begin{array}{l}0.4 \\
0.8 \\
0.6 \\
0.6 \\
1.1\end{array}$ & $\begin{array}{l}0.4 \\
0.8 \\
1.0 \\
1.1 \\
1.1\end{array}$ & $\begin{array}{l}0.4 \\
1.9 \\
1.6 \\
2.5 \\
2.1\end{array}$ & $\begin{array}{r}0 \\
11 \\
4 \\
8 \\
1\end{array}$ & $\begin{array}{r}75 \\
120 \\
131 \\
141 \\
142\end{array}$ & $\begin{array}{l}28 \\
38 \\
48 \\
22 \\
63\end{array}$ \\
\hline 56 & $\begin{array}{l}0 \\
2 \\
3 \\
5\end{array}$ & $\begin{array}{l}4.1 \\
3.9 \\
2.8 \\
1.7\end{array}$ & $\begin{array}{l}0.5 \\
0.5 \\
0.8 \\
0.8\end{array}$ & $\begin{array}{l}0.3 \\
0.4 \\
0.5 \\
0.8\end{array}$ & $\begin{array}{l}0.9 \\
1.4 \\
1.1 \\
1.0\end{array}$ & $\begin{array}{l}0 \\
4 \\
5 \\
1\end{array}$ & $\begin{array}{r}90 \\
110 \\
108 \\
110\end{array}$ & $\begin{array}{l}41 \\
56 \\
42 \\
38\end{array}$ \\
\hline 55 & $\begin{array}{l}0 \\
2 \\
3 \\
5 \\
7\end{array}$ & $\begin{array}{l}3.4 \\
3.2 \\
3.2 \\
2.7 \\
1.4\end{array}$ & $\begin{array}{l}0.4 \\
0.6 \\
0.6 \\
0.7 \\
1.2\end{array}$ & $\begin{array}{l}0.4 \\
0.6 \\
0.6 \\
0.7 \\
0.9\end{array}$ & $\begin{array}{l}0.6 \\
1.4 \\
1.4 \\
0.7 \\
1.3\end{array}$ & $\begin{array}{r}0 \\
11 \\
6 \\
9 \\
0\end{array}$ & $\begin{array}{r}83 \\
120 \\
115 \\
150 \\
148\end{array}$ & $\begin{array}{l}42 \\
41 \\
42 \\
34\end{array}$ \\
\hline .59 & $\begin{array}{l}0 \\
2 \\
3 \\
5 \\
7 \\
9\end{array}$ & $\begin{array}{l}3.3 \\
3.1 \\
3.1 \\
3.1 \\
2.4 \\
1.9\end{array}$ & $\begin{array}{l}0.5 \\
0.5 \\
0.8 \\
0.6 \\
0.7 \\
1.0\end{array}$ & $\begin{array}{l}0.5 \\
0.7 \\
0.5 \\
0.6 \\
0.6 \\
1.4\end{array}$ & $\begin{array}{l}0.5 \\
1.5 \\
1.4 \\
1.9 \\
2.8 \\
1.5\end{array}$ & $\begin{array}{r}0 \\
16 \\
9 \\
16 \\
8 \\
3\end{array}$ & $\begin{array}{r}73 \\
116 \\
110 \\
121 \\
123 \\
134\end{array}$ & $\begin{array}{r}45 \\
38 \\
41 \\
42 \\
38 \\
119\end{array}$ \\
\hline
\end{tabular}

$\$$ Number of antigen additions. 
TABLE II-Continued

\begin{tabular}{|c|c|c|c|c|c|c|c|c|}
\hline \multirow{3}{*}{$\begin{array}{c}\text { Rabbit } \\
\text { no. }\end{array}$} & \multirow{3}{*}{$\begin{array}{l}\text { Time in } \\
\text { months }\end{array}$} & \multicolumn{7}{|c|}{ Serum concentration } \\
\hline & & \multirow[b]{2}{*}{ Alb. } & \multicolumn{3}{|c|}{ Globulins } & \multirow{2}{*}{$\begin{array}{c}\text { Casein } \\
\text { antibody }\end{array}$} & \multirow[b]{2}{*}{ Hexosamine } & \multirow[b]{2}{*}{ NPN } \\
\hline & & & Alpha & Beta & Gamma & & & \\
\hline \multicolumn{9}{|c|}{ Group B-Continued } \\
\hline 47 & $\begin{array}{l}0 \\
2 \\
3 \\
5 \\
7\end{array}$ & $\begin{array}{c}G m . \% \\
3.1 \\
3.7 \\
3.2 \\
3.1 \\
1.4\end{array}$ & $\begin{array}{c}G m . \% \\
0.4 \\
0.7 \\
0.6 \\
0.7 \\
1.1\end{array}$ & $\begin{array}{c}\text { Gm. \% } \\
0.5 \\
0.7 \\
0.7 \\
0.7 \\
0.9\end{array}$ & $\begin{array}{c}\text { Gm. \% } \\
0.3 \\
1.1 \\
0.7 \\
0.9 \\
0.5\end{array}$ & $\begin{array}{l}8 \\
0 \\
0 \\
0 \\
0 \\
0\end{array}$ & $\begin{array}{c}m g . \% \\
95 \\
126 \\
123 \\
128 \\
135\end{array}$ & $\begin{array}{c}m g . \% \\
47 \\
38 \\
37 \\
17 \\
38\end{array}$ \\
\hline 60 & $\begin{array}{l}0 \\
2 \\
5 \\
7 \\
8\end{array}$ & $\begin{array}{l}4.1 \\
3.2 \\
3.0 \\
2.6 \\
2.3\end{array}$ & $\begin{array}{l}0.5 \\
0.6 \\
0.6 \\
0.7 \\
1.0\end{array}$ & $\begin{array}{l}0.6 \\
0.7 \\
0.9 \\
0.9 \\
1.1\end{array}$ & $\begin{array}{l}0.6 \\
1.3 \\
1.3 \\
1.6 \\
1.1\end{array}$ & $\begin{array}{l}0 \\
8 \\
4 \\
5 \\
0\end{array}$ & $\begin{array}{r}80 \\
98 \\
98 \\
112 \\
115\end{array}$ & $\begin{array}{l}39 \\
39 \\
28 \\
37\end{array}$ \\
\hline \multicolumn{9}{|c|}{ Single injection $10 \%$ casein } \\
\hline 61 & $\begin{array}{l}0 \\
2 \\
3 \\
5 \\
7 \\
8\end{array}$ & $\begin{array}{l}3.5 \\
4.2 \\
3.8 \\
4.1 \\
3.9 \\
3.0\end{array}$ & $\begin{array}{l}0.4 \\
0.6 \\
1.0 \\
0.7 \\
0.6 \\
0.7\end{array}$ & $\begin{array}{l}0.3 \\
0.6 \\
0.9 \\
0.7 \\
0.7 \\
0.7\end{array}$ & $\begin{array}{l}0.6 \\
1.4 \\
2.2 \\
2.4 \\
2.6 \\
2.1\end{array}$ & $\begin{array}{l}0 \\
0 \\
0 \\
0 \\
4 \\
1\end{array}$ & $\begin{array}{r}72 \\
97 \\
122 \\
121 \\
121 \\
139\end{array}$ & $\begin{array}{l}33 \\
35 \\
41 \\
\\
25 \\
33\end{array}$ \\
\hline
\end{tabular}

$\$$ Number of antigen additions.

and blocks of tissues were fixed in formaldehyde with $\mathrm{CaCl}_{2}$. Sections were prepared and stained with hematoxylin and eosin, congo red and methyl violet. The liver, spleen and kidney of each animal, as well as subcutaneous nodules, heart and lungs, if they appeared abnormal, were stored in sealed bottles in the deep freeze.

Chemical methods. The total protein of the serum was measured by the $\mathrm{CuSO}_{4}$ method (17) with frequent checks by the gradient density method (18). Serum electrophoresis was obtained by the free-hanging "horizontal strip" method (19) on Whatman No. 1 paper at $22^{\circ} \mathrm{C}$., at 100 volts, $1.5 \mathrm{ma}$, for 16 hours in veronal buffer $(\mathrm{pH} 8.6,0.01 \mu)$. Following staining for proteins with bromphenol blue, the paper strips were cut and each protein fraction eluted with $0.1 \mathrm{~N} \mathrm{NaOH}$ and the optical density determined at $575 \mathrm{~m} \mu$. From this figure and the total protein the amount of protein in each fraction was calculated. The serum hexosamine concentration was determined by the Elson and Morgan reaction as modified by Boas (20). The antibody nitrogen of the casein-antibody precipitate was determined by the Kjeldahl method (21).

Estimations of circulating antibody concentrations were obtained by two different methods. Rabbits of Group A were initially studied by the following method: Following thawing at room temperature, the serum was distributed in $0.5 \mathrm{ml}$. aliquots into each of a series of test tubes. To each tube was added $0.5 \mathrm{ml}$. of saline solutions of casein with nitrogen concentration of $1,800,250,125,62.5,31$ and 7.7 micrograms per $\mathrm{ml}$., respectively. After incubation for 30 minutes at $37^{\circ} \mathrm{C}$., the mixtures were allowed to stand overnight at $0^{\circ} \mathrm{C}$., centrifuged, and the precipitates were graded. The supernatant fluids were tested for anti- gen and antibody excess and the nitrogen values of the antigen-antibody precipitates obtained in the region of slight antigen excess were obtained by the Kjeldahl method (21). From this figure, the antibody nitrogen concentration of the respective serum was calculated and the maximum values for each serum are recorded in Table II.

In Group B rabbits, an estimation of the concentration of antibody was obtained in a different manner. To 1 $\mathrm{ml}$. of serum, $0.25 \mathrm{ml}$. aliquots of casein solution (18 gamma $\mathrm{N}$ per ml.) were added serially on successive mornings. After each addition the mixture was incubated at $37^{\circ} \mathrm{C}$. for 1 hour and then chilled at $0^{\circ} \mathrm{C}$. for approximately 24 hours; the precipitate was centrifuged off and a new $0.25 \mathrm{ml}$. aliquot was then added. This procedure was continued until the addition of antigen failed to yield any precipitate. The number of additions which did yield a precipitate were recorded as an index of the titer of precipitating antibody in that specimen. Simultaneous quantitative determination of the amount of antibody nitrogen obtained in a manner similar to that employed in the Group A rabbits indicated, in several sera studied, that each addition of antigen, containing 4.5 gamma of nitrogen, resulted in the precipitation of approximately 45 gamma of antibody nitrogen.

The specificity of the antigen-antibody precipitation reaction was established by the demonstration that no reaction occurred on cross-reacting casein with anti-bovine plasma albumin rabbit serum, or by reacting bovine plasma albumin (Armour) with anti-casein rabbit serum.

Serum nonprotein nitrogen values, serum uronic acid (22), cryoglobulins (23), and serum cholesterol values were obtained by standard methods. Paper chromato- 
graphic identification of serum hexosamine was done by a method previously outlined (24). The antigen antibody reaction was studied by the agar diffusion method of Ouchterlony (25).

Radioactive methods. In three casein injected rabbits $(59,60,61)$ from series $B$, an attempt was made to determine whether the administered casein was being deposited in the spleens as amyloid. Two normal rabbits served as controls. Approximately $0.2 \mathrm{ml}$. of a solution of $\mathrm{I}^{181}$ labeled sodium caseinate, $8 \mathrm{mg}$. per $\mathrm{ml}$., $(100 \mu \mathrm{c})$, prepared in this laboratory by a modification of the method of Pressman and Eisen (26), was injected subcutaneously as a tracer. The radioactivity of the subcutaneously implanted spleen, of the underlying body wall (from which the spleen had been deflected), and of the original site of injection of labeled casein was then determined at intervals for 24 hours by means of a directional counter. Once the time of maximum uptake by the spleen had been determined (between 4 and 10 hours after injection), a ten-times larger dose of labeled caseinate was administered subcutaneously in multiple sites and the animal was sacrificed after this interval. Aliquots of spleen, kidneys, heart, striated muscle, liver, stomach wall and serum were obtained and determinations of wet weight and radioactivity were obtained, by both direct counting and by radioautography. In two rabbits (No. 60 and one control) radioactive labeled casein was administered daily for 4 days prior to sacrifice, 10 hours after the last injection. Sections of the spleen and kidney were studied radioautographically, and the tissues were weighed and counted as usual.

\section{RESULTS}

\section{A. Clinical and pathological}

The overall incidence of amyloid disease in the rabbits studied, as indicated by biopsy and autopsy, is shown in Table $\mathrm{I}$, in which they are listed in general order of the amount and rapidity of amyloid formation. None of the three control rabbits or of the four which died in less than four months demonstrated amyloid accumulation in any of the organs studied. Repeat biopsy of the spleens of five rabbits in Group B after three and one-half months of injections revealed minimal but definite traces of amyloid in three (Nos. 55, 56 and 58). All of these rabbits went on to display massive amyloidosis at death three and one-half months later. Of the three rabbits which received only one injection of casein, two were free of amyloidosis both at biopsy at three and one-half months and at autopsy five or more months later; one, however (No.61) exhibited a moderate accumulation in the spleen at time of death.

The histologic appearance of the amyloid dis- played a consistent pattern in both groups of rabbits. The earliest visible change in the spleen was the accumulation, especially in perifollicular areas, of small masses of hyaline material, which stained with congo red. In some animals the material was widespread throughout the loose interstitial tissue, as well as in the follicular areas. In others, massive extracellular accumulation appeared in the perifollicular areas, leaving the interstitial tissue largely uninvolved. Finally, in several rabbits the spleen became almost totally replaced, only sparing a few trabeculae and lymphoid follicles. The most common renal abnormality was the accumulation of amyloid substance in the glomeruli, sometimes diffusely along the basement membrane, but occasionally appearing to be engulfed in macrophages. In many of the rabbits the glomeruli were largely or totally replaced by amyloid. In some instances, small amounts of amyloid were also present in the interstitial areas around the collecting tubules. In several rabbits, notably Nos. 47, 56 and 55, there were focal accumulations of polymorphonuclear lymphocytes in the interstitial areas, suggesting pyelonephritis. The livers were usually normal, except for some central hyalinization. In all of the instances noted above, the amyloid stained, at least to some degree, with congo red.

Histologic examination of the heart and skeletal muscles was negative. The nodules present at sites of injection consisted of masses of eosinophilic granular material superficially resembling amyloid but on closer examination, were found to exhibit the appearance of necrotic material and cellular debris and did not stain with congo red. This amorphous material was surrounded by an area of inflammation with infiltration of polymorphonuclear cells.

The clinical course of the rabbits was reviewed in an attempt to identify the characteristics which were manifest by the rabbits which developed severe amyloid disease. There appeared to be no correlation between the distribution of amyloid, degree of organ involvement and the duration of the injections. In six of the rabbits (Nos. 14, 9, $11,58,56$ and 60 ) pea-sized nodules developed at the site of many of the injections, containing thick creamy material having the histologic characteristics mentioned above. The material from one of these yielded a heavy growth of $H$. influenzae on 


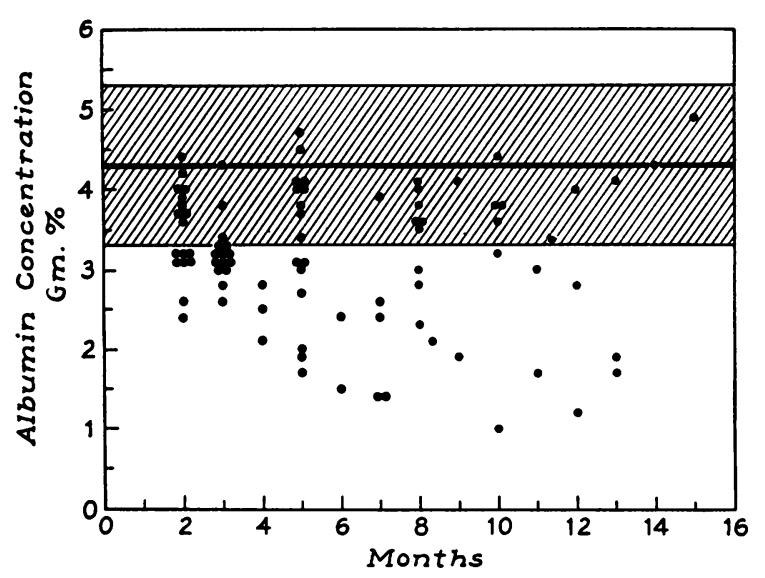

Fig. 1. Serum Albumin

The serum albumin concentration of each rabbit developing amyloidosis is plotted against the months of casein injection. The shaded area represents two standard deviations on either side of the mean of normal values.

culture, whereas several others were sterile. There was no relationship between the presence of these nodules and the amount of amyloid. On the other hand, one rabbit (No. 18) which developed the most massive deposits of amyloid in the shortest period of time had developed, shortly before death, a massive inguinal abscess. Emaciation was con-

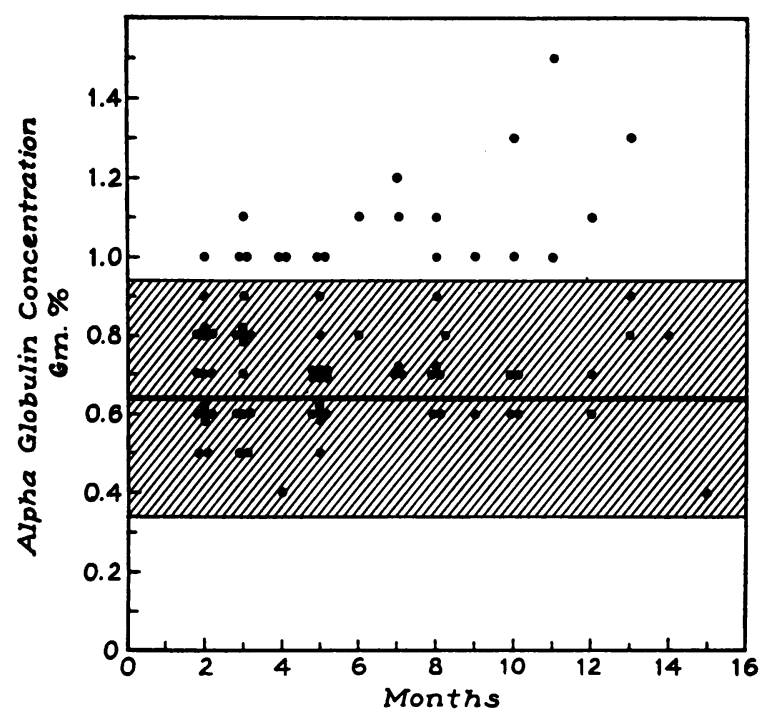

Fig. 2. Alpha Globulin

The serum alpha globulin concentration of each rabbit developing amyloidosis is plotted against the months of casein injection. The shaded area represents two standard deviations on either side of the mean of normal values. spicuous in several of the rabbits, particularly in those with severe renal damage and azotemia.

Only in those animals which died during the first few months of injections, and which did not show amyloid disease, did anaphylaxis appear to be a cause of death. One of these had widespread pulmonary intravascular hyaline deposits, as did one of the animals developing amyloidosis (No. 12). Two animals, one that developed (No. 8) and one that did not develop amyloid, received $25 \mathrm{mg}$. of cortisone intramuscularly daily for one week prior to death; although the cortisone appeared to hasten the development of cachexia and death, no con-

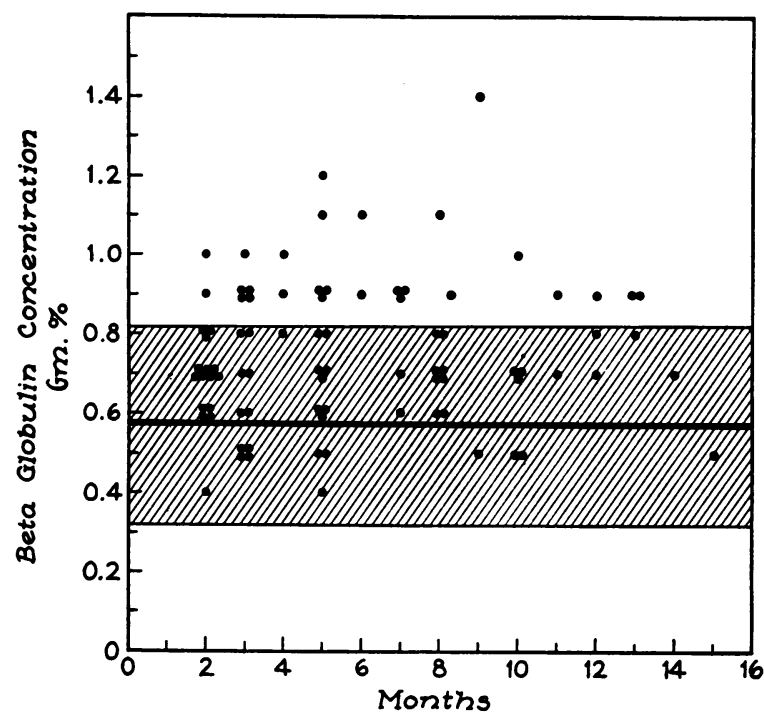

Fig. 3. Beta Globulin

The serum beta globulin of each rabbit developing amyloidosis is plotted against the months of casein injection. The shaded area represents two standard deviations on either side of the mean of normal values.

clusion could be drawn as to its effect upon the development of amyloidosis.

\section{B. Chemical}

The results of the chemical determinations performed on the sera of these rabbits are recorded in Table II.

Electrophoresis of serum. A decrease from normal in the albumin values as determined by paper electrophoresis exceeding two standard deviations was demonstrated at some time in 17 of 18 of the animals developing amyloid (Figure 1). Elevations of the alpha globulins exceeding two stand- 
ard deviations occurred in 13 rabbits (Figure 2). Equally significant deviations of the beta globulins occurred in 15 animals and of the gamma globulins in 13 (Figures 3 and 4). The most marked change in albumin concentration was noted after 10 to 12 months in those rabbits which developed renal disease and azotemia. There was a rough correlation between the amount of hyperglobulinemia and the amount of amyloid (Figure 5).

Serum hexosamine. In nearly all animals receiving serial injections of casein the serum hexosamine concentration had risen two standard deviations within two months (Figure 6), and as a rule it remained persistently elevated throughout

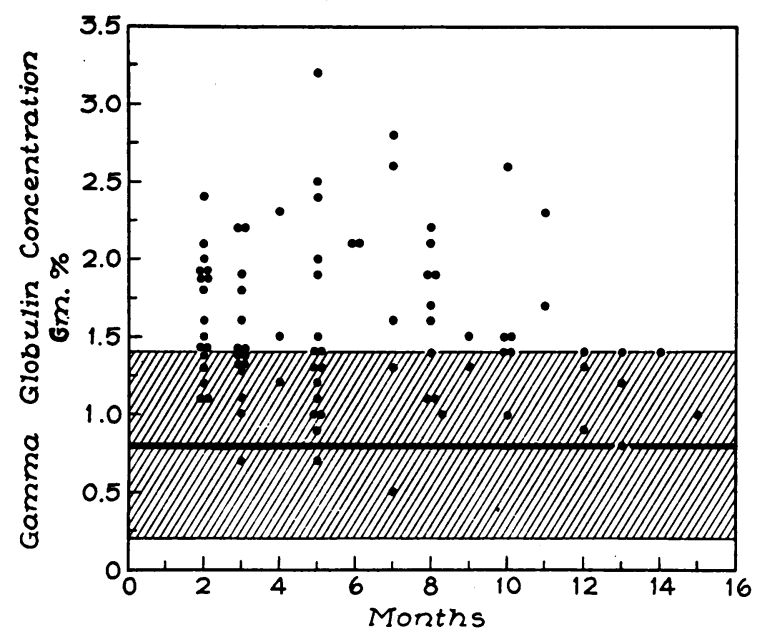

Fig. 4. Gamma Globulin

The serum gamma globulin of each rabbit developing amyloidosis is plotted against the months of casein injection. The shaded area represents two standard deviations on either side of the mean of normal values.

the course of the injections. There also appeared to be a correlation between the severity of the amyloid disease and the increase in hexosamine concentration during the period of injections (Figure 5).

Antibody nitrogen. The precipitable casein antibody nitrogen concentration in the rabbit serum exhibited no definite pattern. Of the eight animals in Group A, two demonstrated high antibody titers (200 to 600 micrograms antibody $\mathrm{N}$ per $\mathrm{ml}$.), three a medium titer (100 to 200 micrograms $\mathrm{Ab} \mathrm{N}$ per $\mathrm{ml}$.), and three either none or a very low titer ( 0 to 100 micrograms $A b N$ per ml.). The highest titer appeared between the

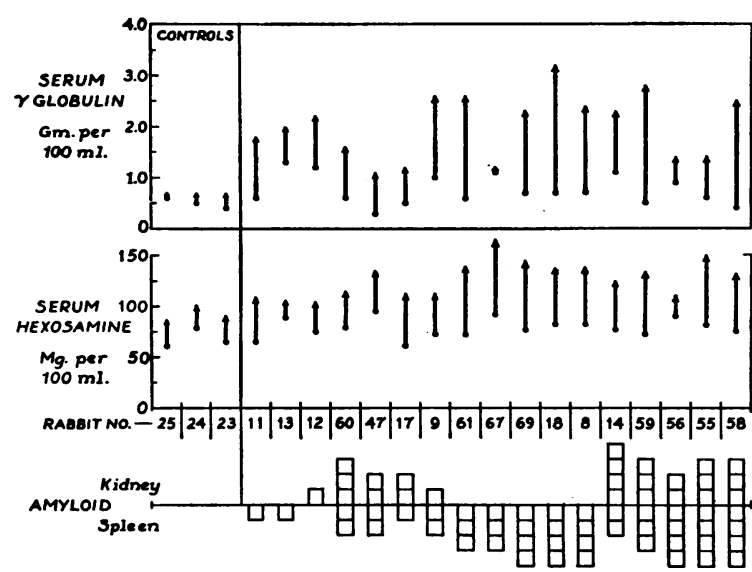

Fig. 5. Relationship of Amyloid Hexosamine and Gamma Globulin

The circle at the base of the arrows is the initial concentration and the tip of the arrow is the highest concentration reached during development of amyloidosis. Each block represents an increment (one plus) of amyloid infiltration of either spleen or kidney.

third and fifth months; usually there was a decrease in titer before death, particularly when associated with cachexia and renal disease. There appeared to be no correlation between the severity of amyloidosis and the antibody titer. The titers of precipitable casein antibody in Group B were in all respects similar to those of Group A (Table II).

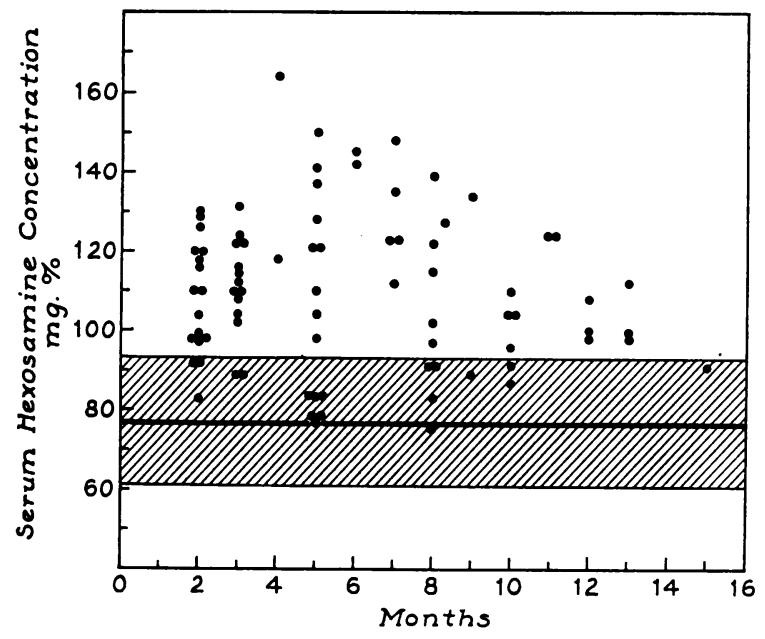

Fig. 6. Serum Hexosamine

The serum hexosamine concentration of each rabbit developing amyloidosis is plotted against the months of casein injection. The shaded area represents two standard deviations on either side of the mean of normal values. 
Serum uronic acid. The values determined serially in eight rabbits, both with and without amyloid, revealed no changes from the normal range except for two markedly elevated levels obtained in two rabbits with severe azotemia. In two other animals with the same degree of azotemia the serum uronic acid concentrations were normal.

Skin tests. In order to detect delayed or tuberculin type of hypersensitivity and immediate type of hypersensitivity, several animals were skin tested with casein (1.2 mg. nitrogen) after five to six months of casein injections. Definite induration and erythema developed, reaching a peak in 4 to 6 hours, and subsiding within 24 hours. There was no reaction of the delayed type, nor did control animals give any reaction.

Serum nonprotein nitrogen $(N P N)$ and cholesterol and lipemia. Serum nonprotein nitrogen concentrations were performed during the course of the study and at the last bleeding on each rabbit in both groups. Five of the seventeen rabbits (Nos. 14, 17, 18, 58, 59) developing amyloid disease showed marked elevations at the last bleeding; each of these rabbits had histologically demonstrable renal damage. Estimations of serum cholesterol, performed in two of the animals with azotemia (Nos. 14 and 17), showed elevated concentrations in both. Normal cholesterol concentrations were obtained in animals which had normal concentrations of blood nonprotein nitrogen. The serum of two rabbits (Nos. 14 and 18) with azotemia exhibited mild to marked lipemia, whereas none of the remaining rabbits, either

TABLE III

The percentage of precipitable casein-antibody in rabbit gamma globulin

\begin{tabular}{|c|c|c|c|c|}
\hline $\begin{array}{c}\text { Rabbit } \\
\text { no. }\end{array}$ & $\begin{array}{c}\text { Casein } \\
\text { precipitable } \\
\text { Ab titer }\end{array}$ & $\begin{array}{c}\text { Casein } \\
\text { precipitable } \\
\text { protein } \\
(\mathbf{A b} \times 6.25)\end{array}$ & $\underset{\text { globulin }}{\text { Gamma }}$ & $\begin{array}{c}\text { Gamma } \\
\text { globulin } \\
\text { precipi- } \\
\text { table by } \\
\text { casein }\end{array}$ \\
\hline $\begin{array}{c}18 \\
8 \\
9 \\
22^{*} \\
4 \\
\text { (1 wk. later) }\end{array}$ & $\begin{array}{c}\mu g . N / m l . \\
710 \\
175 \\
285 \\
570 \\
768 \\
520\end{array}$ & $\begin{array}{l}m g . / m l . \\
4.45 \\
1.1 \\
1.8 \\
3.55 \\
4.8 \\
3.25\end{array}$ & $\begin{array}{c}G m . \% \\
2.1 \\
1.9 \\
1.4 \\
1.5 \\
2.5 \\
1.8\end{array}$ & $\begin{array}{r}\% \\
21 \\
6 \\
13 \\
24 \\
19 \\
18\end{array}$ \\
\hline
\end{tabular}

* Animal No. 22 received 1 per cent casein in Amphogel ${ }_{\circledR}$ five times weekly and is included only in this small study, being part of another study and report. control or receiving injections, demonstrated lipemia. It seems likely that the disturbance in cholesterol and fat metabolism was related to the renal disease rather than to the amyloidosis per se.

Serum cryoglobulins. None were demonstrated during the course of these observations.

Antigen-antibody precipitate. The concentration of hexosamine in twice washed casein-antibody precipitates from the sera of two rabbits that developed amyloidosis was 1 and 1.2 per cent of the precipitating protein. The quantity of hexosamine in the precipitate constituted less than 5 per cent of the total serum hexosamine and thus could not account for any significant amount of the elevated serum hexosamine concentration. The amount of hexosamine found in the precipitate corresponded well with that amount which disappeared from the serum following addition of the casein. The contribution to the hexosamine value by the casein was negligible.

Of further interest was an estimation of the proportion of the gamma globulin that was precipitated by the casein. In six instances the precipitable antibody nitrogen was converted to precipitable antibody protein, and then compared with the gamma globulin as determined by the electrophoresis. Between 6 and 24 per cent (mean, 16.8 per cent) of the gamma globulin was precipitated (Table III).

Chromatography of rabbit serum hexosamine. Because the hexosamine in human amyloid tissue appears to be both glucosamine and galactosamine in a ratio of approximately $4: 1$ (27), it was of interest to study the sera of amyloid rabbits in order to determine whether this same ratio was present. No galactosamine was demonstrable, however, in the sera by paper chromatography. In sera from three rabbits, hexosamine was determined before and after dialysis against isotonic saline ( $\mathrm{pH} 7)$. In no case did the concentration decrease.

Agar diffusion antigen-antibody studies. The rabbit serum antibodies to the casein used in the production of amyloid were studied by the Ouchterlony agar diffusion technique (25). Against that casein four distinct bands were noted in the agar. Furthermore, the serial bleedings from a given animal showed changing intensity of the different bands during the course of the injections. Casein is known to have three electrophoretic 
components. The presence, however, of four agar diffusion bands suggested that impurities in the casein had served as antigens. Therefore, these same sera were also tested against casein ${ }^{5}$ that had been reprecipitated several times, but the same number and intensity of agar diffusion bands resulted. Sera from control animals gave no bands.

Radioactive studies. The rates of declining radioactivity at the sites of injection of $\mathrm{I}^{131}$ labeled casein and of increasing activity over the parenchymal organs were similar in all rabbits studied, whether or not they had received serial injections of casein. The radioactivity at the site of injection fell to less than 40 per cent of its initial value within 3 hours and reached between 5 and 15 per cent of its initial value in 10 hours. There was no difference in radioactivity of the spleen and of the body tissues immediately beneath the spleen at any time following the injection, either in the control or the injected animals. This activity reached its peak between 4 and 10 hours after the time of injection, the time curves showing no consistent difference between the two groups. No significant uptake of radioactive material was noticed in the region of the thyroid gland.

Upon sacrificing the animal no significant differences in radioactivity were noted between tissues which were laden with amyloid and the relatively normal organs. Radioautographic studies showed no concentration of labeled material in the areas of amyloid deposits. It was concluded that no uptake of $\mathrm{I}^{131}$ labeled casein by the amyloid tissue could be demonstrated by this method.

\section{DISCUSSION}

It must be pointed out at the outset that there is no proof that so-called amyloidosis in experimental animals is the same disease as amyloidosis in human beings. On the other hand, the histological appearance of the deposits, including staining reactions, is similar in both conditions; the course of the disease is parallel and both in human beings and in experimental animals the disease is prone to develop in situations resulting in prolonged taxation of the defense mechanisms of the host. Indeed, except for the fact that experimental amyloidosis, in rabbits at least, seldom involves the liver to any great extent, the two conditions are quite comparable. Since, in the last analysis

\footnotetext{
${ }^{5}$ Obtained from Dr. David Waugh, Massachusetts Institute of Technology, Cambridge, Mass.
}

no one knows the nature or cause of human amyloidosis, attempts to gain perspective by considering so analagous an experimental disorder do not seem inappropriate.

It is apparent from the above study that biweekly subcutaneous injection of sodium caseinate $(0.5 \mathrm{Gm}$.) is an effective method of inducing amyloidosis in rabbits. Of 14 animals receiving serial injections and surviving for four months or more, all exhibited the disease to some degree. Individual susceptibility appeared to be a greater determinant than duration of injections. Thus, three of the rabbits studied by biopsy exhibited moderated amyloidosis after three and one-half months of injections and displayed massive amyloid deposits by the time of sacrifice, three and one-half months later. On the other hand, one animal (No. 11) displayed only minimal evidence of the disease after a 15 month course of injections totalling $64 \mathrm{Gm}$. of casein.

Because one of the rabbits with severe amyloidosis in this series (No. 18) had a secondary infection, it is suggested that secondary infection may predispose the animal to more severe disease. On the other hand, in a subsequent study, culture of both the casein preparations used for injection and the subcutaneous nodules were sterile, indicating that secondary infection is neither frequent nor necessary in the development of amyloidosis by casein injections.

The studies on our rabbits indicated that many but not all of those animals which exhibited hypergammaglobulinemia during the course of the injections were the ones which developed massive amyloid deposits (see Figure 5). Other investigators have noted that hyperglobulinemia is a frequent antecedent to experimental amyloidosis, induced by a variety of agents $(2,3,7,12,13)$. The nature of the association between hyperglobulinemia and amyloidosis is unknown.

Eklund and Reimann (3) commented not only upon the fact that hyperglobulinemia preceded the development of amyloidosis, but also upon the hypoalbuminemia appearing after the development of renal amyloidosis and azotemia. Our own studies likewise indicate that only those rabbits developing azotemia, as a terminal complication of amyloidosis, exhibited a decrease in albumin concentration. The hypercholesterolemia and lipemia, the marked rise in serum uronic acid concentration, and the terminal fall in serum albumin 
concentrations and in casein antibody titer seemed to be dependent upon the development of renal insufficiency and are probably not related to the pathogenesis of amyloidosis.

Elevation of the serum hexosamine has been reported in one instance of human amyloidosis (14) as well as in a wide variety of other diseases and during stress in animals. In addition, amyloidcontaining tissues have been shown to contain a higher concentration of hexosamine than normal tissues $(27,28)$. In this study there appeared to be significant correlation between the degree of elevation of the serum hexosamine and the amount of amyloid present at autopsy (Figure 5). Further studies of the serum hexosamine indicate that it is nondialyzable, presumably protein bound, and predominantly or entirely glucosamine. Inasmuch as the serum uronic acid concentration did not increase in parallel fashion, it can be presumed that the glucosamine was probably not in the form of hyaluronic acid or another acid mucopolysaccharide. These data, therefore, suggest that the serum hexosamine component may have been glycoprotein in nature distinct from the antibodies precipitable by casein.

The demonstration of precipitable antibodies to casein in the sera of rabbits developing amyloidosis in the study is of interest in several respects. Some of the animals developed within two months' time moderately high titers of antibody to the casein, while others developed minimal or undetectable amounts of antibody even after 15 months of casein injections. The absence of apparent relationship between the amount of circulating antibody and the degree of amyloidosis reflected by this data does not necessarily refute the concept of others $(13,15,16)$ that amyloid represents a deposit of an antigen-antibody complex. Vazquez and Dixon (16), using fluorescent labeling techniques, have recently furnished the best evidence for this concept by detecting both gamma globulin and casein in the amyloid induced in rabbits by casein injections, though it must be pointed out that the gamma globulin and casein by this technique may constitute only a very small portion of the amyloid. It is entirely possible that the rapid precipitation of such a complex might have removed antibodies from the serum of our animals. The failure, however, to demonstrate $\mathrm{I}^{131}$ labeled casein in the amyloid of our rabbits leaves open the question as to whether amyloid is an antigenantibody precipitate.

However, evidence is more conclusive that amyloid is not solely an accumulation of the antigen, i.e., casein in this study. The presence of a significant hexosamine concentration in the amyloid of these animals (28) in contrast to the absence of hexosamine in casein is evidence that amyloid is not pure casein. Furthermore, one animal (No. 61) developed extensive amyloidosis after only one injection of casein ( $500 \mathrm{mg}$. total of casein). Finally, the failure of $\mathrm{I}^{131}$ labeled casein to be detected in the amyloid of these animals suggests that the amyloid was not pure casein.

Some peculiar antigenic properties of casein deserve comment. Although casein is known to have at least three electrophoretic components, the observation of four agar diffusion precipitin bands when testing the rabbit sera against casein, both that used for the injection and a reprecipitated preparation, suggests that a complex of these casein components (29) may serve as an antigen or the casein may in some fashion stimulate a heterogenous antibody. Such a complex antigenantibody system may be difficult to evaluate by the quantitative precipitin technique used in the Group A animals, because the equivalence points may differ among these four antigen-antibody systems. Such difficulties in addition to the Danysz' phenomenon (30) may enter in the results obtained in the Group B animals.

The evidence presented above suggests that in these rabbits prolonged elevation in the concentration of serum globulins and hexosamine containing compounds may be associated with the eventual appearance of amyloid. Although no relationship was demonstrated between the serum precipitable antibody and the development of amyloidosis, there remains the definite possibility that nonprecipitating antibodies or other immunologic factors are intimately involved in the pathogenesis of amyloidosis.

\section{CONCLUSIONS}

1. Serial injections of sodium caseinate is a very effective, although slow and not entirely predictable, method of inducing massive deposits of amyloid in rabbits.

2. Elevation of all the globulins occurred both before and during the development of amyloidosis. 
A fall in albumin concentration occurred in those animals which developed terminal renal insufficiency.

3. Elevation of the serum hexosamine concentration occurred throughout most of the course of injections in all of the rabbits which developed amyloidosis.

4. Significant titers of circulating antibodies could be demonstrated in many animals; while in general, the rabbits which exhibited the highest antibody concentrations developed large amyloid deposits, several animals developed definite deposits without having exhibited circulating antibodies.

\section{ACKNOWLEDGMENT}

The authors are indebted to Dr. Walter Bauer for his encouragement and suggestions throughout the course of this study.

\section{REFERENCES}

1. Bailey, C. H. The production of amyloid disease and chronic nephritis in rabbits by repeated intravenous injections of living colon bacilli. J. exp. Med. 1916, 23, 773.

2. Dick, G. F., and Leiter, L. Some factors in the development, localization and reabsorption of experimental amyloidosis in the rabbit. Amer. J. Path. 1941, 17, 741.

3. Eklund, C. M., and Reimann, H. A. The etiology of amyloid disease; with a note on experimental renal amyloidosis. Arch. Path. 1936, 21, 1.

4. Gellhorn, A., van Dyke, H. B., Pyles, W. J., and Tupikova, N. A. Amyloidosis in hamsters with leishmaniasis. Proc. Soc. exp. Biol. (N. Y.) 1946, 61, 25.

5. Grayzel, H. G., Jacobi, M., Marshall, H. B., Bogin, M., and Bolker, H. Amyloidosis: Experimental studies. Arch. Path. 1934, 17, 50.

6. Hass, G. M., Huntington, R., and Krumdieck, N. Amyloid. III. The properties of amyloid deposits occurring in several species under diverse conditions. Arch. Path. 1943, 35, 226.

7. Latvalahti, J. Experimental studies on the influence of certain hormones on the development of amyloidosis. Acta endocr. (Kbh.) 1953, Suppl. 16.

8. Pirani, C. L., Bly, C. G., Sutherland, K., and Chereso, F. Experimental amyloidosis in the guinea pig. Science 1949, 110, 145.

9. Rothbard, S., and Watson, R. F. Amyloidosis and renal lesion induced in mice by injection with Freund-type adjuvant. Proc. Soc. exp. Biol. (N. Y.) 1954, 85, 133.

10. Tolone, S., and Pansini, H. Nuovo metodo di produzione dell'amiloidosi sperimentale. Boll. Soc. ital. Biol. sper. 1949, 25, 1008.

11. Hoffman, I., Friedfeld, L., Fishberg, E. H., and Fishberg, A. M. Amyloidosis and hypertension in cholesterol-fed rabbits. Proc. Soc. exp. Biol. (N. Y.) 1951, 78, 37

12. Fishberg, A. M., Friedfeld, L., Hoffman, I., Stoller, E. R., and Fishberg, E. H. Beta-hyperglobulinemia produced by cholesterol feeding in the rabbit. Proc. Soc. exp. Biol. (N. Y.) 1950, 75, 301.

13. Peräsalo, O., and Latvalahti, J. Amyloid degeneration in the light of clinical and experimental studies. Acta path. microbiol. scand. 1954, 34, 208.

14. Faber, M. Serum glucosamine with particular regard to its significance in connection with the origin of amyloid deposits. Acta med. scand. 1948, Supp. 206, 351.

15. Letterer, E. Some new aspects of experimental amyloidosis. J. Path. Bact. 1949, 61, 496.

16. Vazquez, J. J., and Dixon, F. J. Immunohistochemical analysis of amyloid by the fluorescence technique. J. exp. Med. 1956, 104, 727.

17. Hawk, P. B., Oser, B. L., and Summerson, W. H. Practical Physiological Chemistry, 12th ed. Philadelphia, The Blakiston Company, 1947, p. 553.

18. Lowry, O. H., and Hunter, T. H. The determination of serum protein concentration with a gradient tube. J. biol. Chem. 1945, 159, 465.

19. McDonald, H. J. Ionography: A new frontier in electrophoresis. J. chem. Educ. 1952, 29, 428.

20. Boas, N. F. Method for the determination of hexosamines in tissues. J. biol. Chem. 1953, 204, 553

21. Kabat, E. A., and Mayer, M. M. Experimental Immunochemistry. Springfield, Charles C Thomas, 1948.

22. Fishman, W. H., Smith, M., Thompson, D. B., Bonner, C. D., Kasdon, S. C., and Homburger, F. Investigation of glucuronic acid metabolism in human subjects. J. clin. Invest. 1951, 30, 685.

23. Lerner, A. B., Barnum, C. P., and Watson, C. J. Studies on cryoglobulins. II. The spontaneous precipitation of proteins from serum at $5^{\circ} \mathrm{C}$ in various disease states. Amer. J. med. Sci. 1947, $214,416$.

24. Stoffyn, P. J., and Jeanloz, R. W. Identification of amino sugars by paper chromatography. Arch. Biochem. 1954, 52, 373.

25. Ouchterlony, O. Antigen-antibody reactions in gels. IV. Types of reactions in coordinated systems of diffusion. Acta path. microbiol. scand. 1953, 32, 231.

26. Pressman, D., and Eisen, H. N. The zone of localization of antibodies. V. An attempt to saturate antibody-binding sites in mouse kidney. J. Immunol. 1950, 64, 273.

27. Giles, R. B., Jr., and Calkins, E. Studies of the composition of secondary amyloid. J. clin. Invest. 1955, 34, 1476.

28. Calkins, E., Cohen, A., and Giles, R. B. Unpublished observations.

29. McMeekin, T. L. The milk proteins in The Proteins, H. Neurath and K. Bailey, Eds. New York, Academic Press Inc., 1954, vol. II, p. 389.

30. Sherwood, N. P. Immunology. St. Louis, C. V. Mosby Co., 1941, p. 253. 